REVIEW / ARTÍCULO DE REVISIÓN

\title{
Hormonal and neuroendocrine control of reproductive function in teleost fish
}

Abstract: Reproduction is one of the most important physiological events for the maintenance of the species. Hormonal and neuroendocrine regulation of teleost requires multiple and complex interactions that take place along the hypothalamic-pituitary-gonad (HPG) axis. Within this axis, gonadotropin-releasing hormone (GnRH) regulates synthesis and release of gonadotropins, follicle stimulating hormone (FSH) and luteinizing hormone (LH). Steroidogenesis drives reproduction function in which the development and differentiation of gonads. In recent years, new neuropeptides have become the focus of reproductive physiology research as they are involved in the different regulatory mechanisms of the growth, metabolism, and reproduction of these species. However, especially in fish, the role of these neuropeptides in the control of reproductive function is not well studied. The study of hormonal and neuroendocrine events that regulate reproduction is crucial for the development and success of aquaculture.

Key words: Hormonal control, neuroendocrine, reproductive function, teleost fish, aquaculture.

\section{Introduction}

quaculture is the fastest-growing food production sector globally and plays an essential role in meeting the food demand of populations. In this stage, incorporating new technologies that allow increasing the number of cultivable species is crucial $^{1,2}$. For several years, the aquaculture sector has focused mainly on establishing the minimum requirements for the development, growth, and reproductive success of the different species ${ }^{3,4}$. The study of endocrinology in teleost fish has been fundamental for understanding the functional roles of hormones in biological systems. In recent years, the existence of a complex and infinite number of interactions between hormones and nerve structures has been demonstrated ${ }^{5-9}$. Reproduction is one of the most important biological processes of organisms since the survival and perpetuation of the species depend on it ${ }^{1,10}$. The control of reproductive events allows the application of selection programs to improve the growth rate, the survival of the species, reduce the problems associated with sexual maturation and generate monosex populations $^{11,12}$. The quality of spawning depends on environmental factors such as photoperiod, temperature, salinity, tank volume, substrate vegetation, etc ${ }^{1,13}$. The initiation of reproduction is affected by the number of energy reserves in the body and is sensitive to various metabolic factors.

The neuroendocrine mechanisms responsible for the association between energy balance and fertility are represented by metabolic hormones and neuropeptides that affect the hypothalamic center. In teleosts, as in other vertebrates, reproduction is coordinated by the hypothalamic-pituitary-gonad (HPG) axis ${ }^{14-16}$. However, there is very little research on reproductive biology and these species' molecular and cellular mechanisms ${ }^{12,17,18}$. This review presents a general bibliographic compilation of the main hormonal and neuroendocrine aspects of the control of reproductive function in teleost fish. Therefore, it will try to provide an overview of the most significant findings in recent years.

\section{Hormonal control of reproduction in teleost fish}

The control of reproduction in fish is a multifactorial process involving environmental, social, neuronal, endocrine, and metabolic agents. a cascade of hormones regulates ${ }^{19,20}$ reproduction. The mechanisms involved in this process depend on

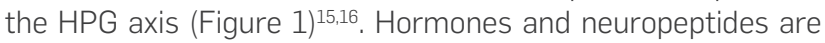
produced in specific neuronal regions of the brain, mainly in the hypothalamus. These can directly inhibit or stimulate gonadotropins $(\mathrm{GtH})$ release into the bloodstream or indirectly through their functions on gonadotropin-releasing hormone $(\mathrm{GnRH})^{21,19}$. The beginning of sexual maturation in fish presents two simultaneous events: the release of gonadotropin-releasing hormone $(\mathrm{GnRH})^{22-25}$ and the activation of $\mathrm{GtH}$ receptors in the gonads ${ }^{26}$. The activation of these receptors stimulates the production of germ cells, the synthesis of sex steroids and growth factors, and the effectors of gonadal development ${ }^{12,27,19}$. At the level of the pituitary gland, different molecules are secreted, such as: luteinizing hormone $(\mathrm{LH})$, follicle-stimulating hormone $(\mathrm{FSH})$, growth hormone $(\mathrm{GH})$, prolactin (PRL), thyroid-stimulating hormone $(\mathrm{TSH})$, among others ${ }^{21}$. These hormones participate in osmoregulation processes, growth, gonadal steroid production, the onset of pu- 
berty, and reproductive behavior of fish,7,22,28-30. In addition, a series of neuroendocrine factors and hypothalamic neuropeptides have been identified that regulate behavior, eating, and energy balance. Their physiological and metabolic functions guarantee survival and growth during the reproductive stage ${ }^{16}$. Within these neuropeptides, we can mention the $\mathrm{GH}$ releasing hormone $(\mathrm{GHRH})$, pituitary adenylate cyclase-activating polypeptide (PACAP), Somatostatin (SS), the thyrotropin-releasing hormone (TRH), Dopamine, Neuropeptide-Y ( NPY), gamma-aminobutyric acid (GABA), neurokinin $B(N K B)$ and gonadotropin inhibiting hormone $(\mathrm{Gn} \mid \mathrm{H})^{18,31-36}$. In addition, among these neuropeptides is also included Kisspeptin (Kiss) ${ }^{37}$, which constitutes an important regulator of the synthesis and release of $\mathrm{GnRH}^{38,39,40,41}$. Another very novel neuropeptide is Phoenixin (PNX), which regulates physiological processes such as food consumption, proliferation, and cell differentiation ${ }^{42,43}$. Moreover, it has been reported to be involved in reproductive function; due to its role in gene expression regulation in the hypothalamus and pituitary ${ }^{44,45}$. High concentrations of phoenixin in the central and peripheral nervous systems suggest that the peptide may serve as a multi site-directed signaling molecule $e^{44,46,47}$. In general, these brain factors, in addition to being involved in the secretion of pituitary hormones, regulate other physiological systems, but they greatly influence reproduction $12,30,36,48$. At each level of the axis, a limited number of target cells are under the influence of many factors. The final cellular response is the overall effects of these mediators on the components of intracellular signal transduction ${ }^{49}$. Mature gonads secrete sex steroids (estrogens and androgens), which negatively regulate hormonal secretions in the hypothalamus and pituitary gland. This closed-loop system maintains the homeostasis of the reproductive system ${ }^{12}$. In general, according to their functions on the reproductive cycle, FSH has a vitellogenin function and LH a maturational function ${ }^{50-53}$.

\section{Gonadotropin-releasing hormone (GnRH)}

In fish, as in all vertebrates, reproduction is regulated by the hypothalamus through gonadotropin-releasing hormone $(\mathrm{GnRH})^{16,54}$. This hormone constitutes the critical element of the neuroendocrine control of reproduction ${ }^{16,55-58}$. The (GnRHs) constitute a family of peptide molecules whose nature and diversity have been evidenced in teleost fish ${ }^{59}$. Three structural variants of $\mathrm{GnRH}$ have been identified in various vertebrate species: $\mathrm{GnRH} 1, \mathrm{GnRH} 2$, and $\mathrm{GnRH} 3^{56,57,58,60,61}$. However, the molecular mechanisms that link the 3 isoforms of $\mathrm{GnRH}$ with reproduction in fish are not well clarified ${ }^{62}$.Mammals only possess $\mathrm{GnRH} 1$ and $\mathrm{GnRH} 2$, while teleost fish have two or all three types of $\mathrm{GnRH}^{41}$. Most teleost fish, including Perciformes and Pleuronectiformes, present all three $\mathrm{GnRH}$ isoforms ${ }^{36,55,57,63}$ Other fish species such as salmon (Salmoninae), zebrafish (Danio rerio) and goldfish (Carassius auratus) possess only two forms of $\mathrm{GnRH}(\mathrm{GnRH} 2 \text { and } \mathrm{GnRH} 3)^{14,36,64,65} \mathrm{GnRH} 1$ is expressed mainly in the olfactory bulb, ventral telencephalon, and the pre-optic zone. GnRH2, a conserved form from fish to mammals, is expressed mainly in the midbrain ${ }^{36}$.

$\mathrm{GnRH} 3$ constitutes the specific form of $\mathrm{GnRH}$ in fish ${ }^{66,67}$ and has a similar distribution to $\mathrm{GnRH} 1$. The three structural variants of $\mathrm{GnRH}$ have different physiological functions.

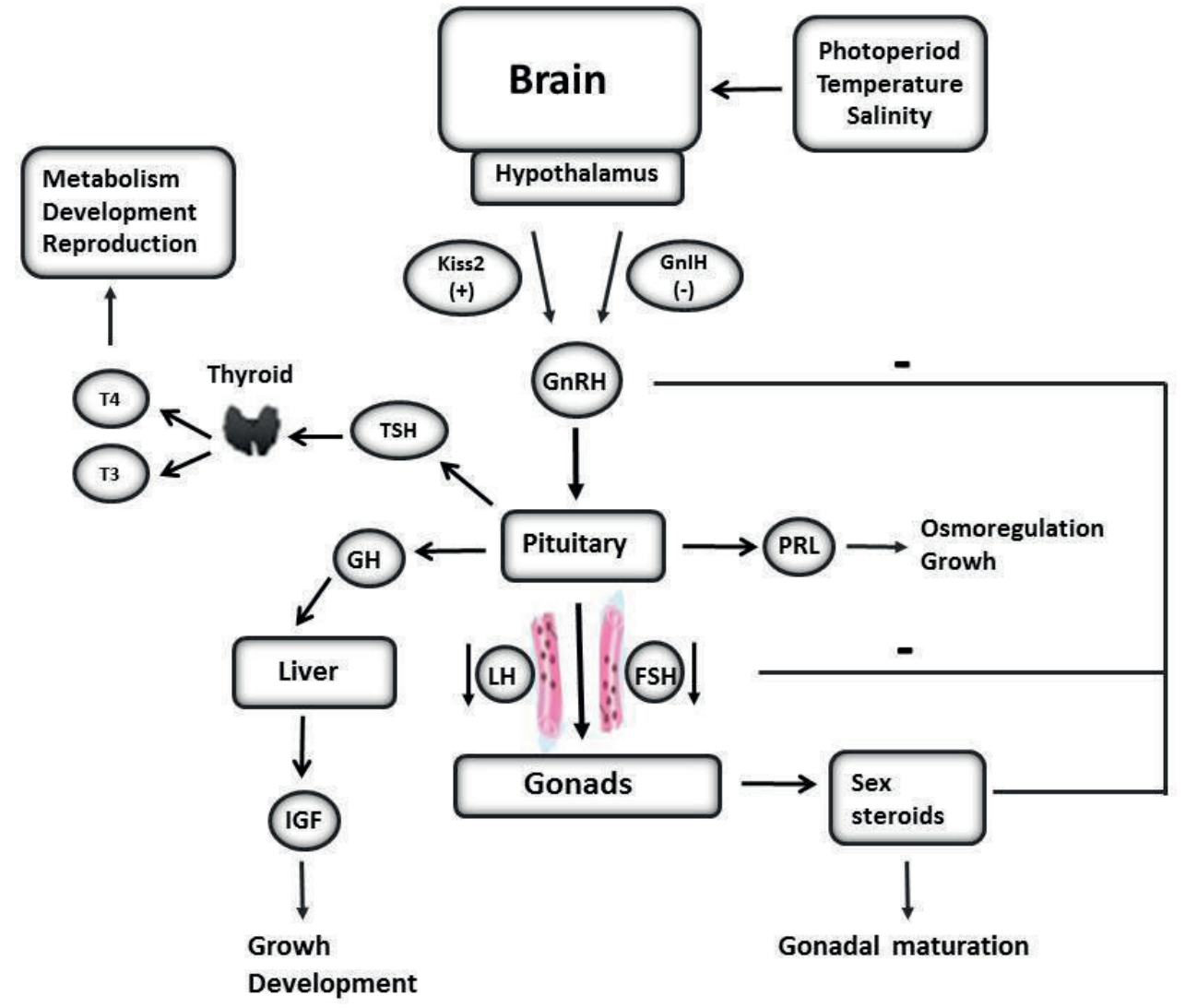

Figure 1. Hypothalamic-Pituitary-Gonads (HPG) axis. Gonadotropin-Releasing Hormone (GnRH); follicle-stimulating hormone $(\mathrm{FSH})$; luteinizing hormone (LH); prolactin (PRL); growth hormone (GH); Kisspeptin (Kiss2); Gonadotropin inhibitory hormone $(\mathrm{GnIH})$; Growth factors (IGF); Thyroid-stimulating hormone (TSH); Triiodothyronine (T3); Tetraiodothyronine (T4). GnRH secretion acts on a population of gonadotropic cells of the pituitary, which release LH and FSH. In addition, the pituitary is the site of synthesis, storage, and release of $\mathrm{GH}, \mathrm{TSH}$, and $\mathrm{PRL}$; it is considered a transducer that, through its secretions, regulates endocrine functions, such as reproduction, osmoregulation, growth, and metabolism. 
$\mathrm{GnRH} 1$ is considered the hypothalamic variant capable of stimulating gonadotropin secretion and constitutes the fundamental regulator of the pituitary in mammals ${ }^{56,58}$. In teleost fish, GnRH1 has its physiological importance in the regulation of gonadotropin secretion and gametogenesis ${ }^{14}$. GnRH2 is involved in regulating eating behavior $58,68,69,70,71$ and probably has an intermediary role between food intake and reproduction ${ }^{72,73}$. It is highly probable that both $\mathrm{GnRH} 2$ and other $\mathrm{GnRH}$ isoforms expressed in the olfactory region play a role in the perception of social and pheromonal signals ${ }^{36,74}$. GnRH3 participates in the control of reproductive behaviors in several fish species ${ }^{14}$ .For example, this isoform stimulates the nesting behavior of male dwarf Gourami (Trichogaster Lalius) ${ }^{14}$. In adult zebrafish lacking GnRH3 neurons, there was evidence of an arrest in oocyte development and also a reduction in the mean diameter of the oocytes. These findings suggest that hypophysiotropic GnRH3 neurons are critical for normal oocyte development and reproduction ${ }^{75}$. Both this study and those carried out by Palevitch et al. $2007^{76}$, suggest that GnRH3 is the hypophysiotropic GnRH capable of regulating the HPG axis in species lacking $\mathrm{GnRH} 1$, such as zebrafish. The action of GnRHs on target cells is mediated by specific binding to their membrane receptors $(\mathrm{GnRHR})^{36}$. Corresponding to the primary role of $\mathrm{GnRH}$ in controlling reproduction, GnRHRs are mainly localized in the brain to mediate the neuromodulatory actions of $\mathrm{GnRH}$ in other neuronal systems and in gonadotropic cells of the pituitary to regulate gonadotropin secretion. Furthermore, GnRHRs, like GnRHs, are found in the gonads and other peripheral tissues, exerting multiple physiological actions ${ }^{36,77}$. In general, the primary function attributed to $\mathrm{GnRH}$ is the stimulation of the synthesis and release of $\mathrm{GtH}$ in teleost fish ${ }^{36,55,77-81}$ Besides, it can regulate the gonadal maturation, the development of germ cells (oogenesis and spermatogenesis), gonadal steroid production, ovulation, spermiation, and spawning ${ }^{36,57}$ In addition, it is involved in the control of the release and expression of growth hormone, somatolactin, and prolactin ${ }^{82,83}$. Considering the published results in the literature, the effects of GnRHs on the control of reproductive function depend on the species, sex, and reproductive status, as well as the complex endocrine interactions along the HPG axis ${ }^{57,83}$.

\section{Kisspeptin}

Kisspeptin regulates the HPG axis ${ }^{34,84,85,86}$, and in the initiation of sexual maturation ${ }^{84,87}$. Kisspeptin expression is more abundant in the brain, particularly in the hypothalamus ${ }^{84,88}$. It originates from neuronal populations in the hypothalamus and projects into the median eminence $(E M)$ and preoptic area (POA) regions, where $\mathrm{GnRH}$ neurons are also found ${ }^{89,90,91}$. However, its expression has been evidenced in peripheral tissues such as the intestine, kidney, liver, pancreas, adipose tissue, and gonads ${ }^{92}$. In mammals, only (kissl) coding for kisspeptin and (kisslr) coding for the receptor have been identified ${ }^{93}$. However, in some teleost species due to a third duplication of the genome, two genes coding for kisspeptin (kiss1 and kiss2) have been identified ${ }^{86,93}$ Some of these species are medaka (Oryzias latipes) $^{84}$, zebrafish ${ }^{84,94}$, sea bass (Lateolabrax japonicus), and redfish (Sciaenops ocellatus) ${ }^{95}$. Other species, such as the puffer fish (Takifugu niphobles) ${ }^{87}$ and Senegalese sole (Solea senegalensis) contain only the kiss2 gene ${ }^{96}$. The kisspeptin receptor (kiss-R) in fish is expressed in tissues such as the brain, pituitary, gonads, heart, kidney, liver, and muscle 84,87,97-99. $^{\text {. }}$ Different teleosts species have two or even three genes encoding for kisspeptin receptors (kiss 1r, kiss2r, kiss3r) ${ }^{93,100}$. For example, kiss1r and kiss2 $r$ have been identified in medaka, ze- brafish, goldfish, striped bass (Morone saxatilis), and European bass (Dicentrarchus labrax). However, kiss2r has only been identified in Nile tilapia (Oreochromis niloticus), cobia (Rachycentron canadum), gray mullet (Mullus barbatus), spotted grouper (Epinephelus fuscoguttatus), Senegalese sole, among others ${ }^{101}$. Kiss3r, the expression demonstrated in zebrafish ${ }^{97}$, goldfish ${ }^{102}$, medaka ${ }^{103}$, striped bass (Zmora et al., 2012), and European eel (Anguilla anguilla) ${ }^{104}$. There is evidence in fish of the participation of kisspeptins and their receptors in the feedback mechanisms of sex steroids ${ }^{40}$. The role of kisspeptin in reproduction is based mainly on the stimulation of $\mathrm{GnRH}$ release, indirectly modulating the release of $\mathrm{LH}$ and $\mathrm{FSH}^{93,105}$. In mammalian models, kisspeptin regulates the release of $\mathrm{LH}$ through projections on $\mathrm{GnRH}$ neurons. However, in the case of teleosts, these functions are not clear ${ }^{62}$. Zhao et al. $2014^{106}$ provided interesting data on the modulatory effects of kiss1 and kiss2 on neuronal GnRH subpopulations. First, they reported that treatment with kiss1 or kiss2 during the first day after fertilization stimulated the proliferation of $\mathrm{GnRH} 3$ neurons in the peripheral nervous system. However, only kiss 1 stimulated the proliferation of terminal and hypothalamic nerve populations of $\mathrm{GnRH} 3$ neurons ${ }^{106}$. In zebrafish $(\mathrm{GnRH} 3)$ and striped bass $(\mathrm{GnRH} 1)$, few preoptic $\mathrm{GnRH}$ neurons appear to be innervated by kisspeptin ${ }^{94,107,108}$. However, European seabass (Dicentrarchus (abrax) and medaka hypothalamic GnRH3 neurons are not associated with kisspeptin fibers ${ }^{88,109}$. Zmora et al. 2015 ${ }^{110}$, found kissl immunoreactive nerve endings that reach LH cells, suggesting the existence of a direct pituitary site of action of kisspeptin These results are similar to those published by Shahjahan et al. in $2014^{14}$ where the expression of kisspeptin is evidenced in the pituitary gland of goldfish and puffer fish (Takifugu rubripes). Studies in goldfish ${ }^{37,99}$ and sea bass ${ }^{111}$ have confirmed a direct stimulation in the secretion of LH and FSH in pituitary cells in response to kisspeptin administration. On the other hand, in goldfish, kissl significantly increased LH- $\beta$, $\mathrm{GH}$ and PRL mRNA levels through in vitro studies ${ }^{99}$. Interestingly, both kiss1 and kiss2 regulate FSH- $\beta$ expression levels in pituitary cell cultures in striped bass (Morone saxatilis). However, only Kissl can regulate LH- $\beta$ mRNA levels in seabass negatively ${ }^{110}$. In sexually mature female zebrafish, administration of Kiss2 by intraperitoneal injection significantly increased FSH and LH mRNA levels. On the other hand, the administration of kissl by the same route did not have significant differences in $\mathrm{GtH}$ gene expression levels ${ }^{84,112}$. The stronger effect of kiss2 compared to kiss1 was also observed in the release of FSH and LH in sea bass ${ }^{95,112}$. A similar trend was observed for the effects of kisspeptins on the stimulating effect on gonadal maturation in seabass and striped bass ${ }^{113}$. In contrast, intraperitoneal injections of kiss2 stimulated mRNA expression of $\mathrm{FSH}$ rather than $\mathrm{LH}$ in female spotted grouper ${ }^{114}$. Furthermore, in goldfish, intraperitoneal injections of kiss1, but not kiss2, stimulated the release of $\mathrm{LH}$ in sexually mature females ${ }^{102}$. Also, it has been reported that kiss 2 may have effects on food intake and growth function ${ }^{88,96,115}$. Furthermore, it can act as a link between food intake, energy homeostasis, and reproduction ${ }^{116-118}$. In general, these findings indicate the role of kiss1 and kiss2 in gonadotropin regulation is species-specific. Collectively, the differences between the species derive from their reproductive behavior and the stages of reproduction.

\section{Gonadotropin inhibitory hormone (GnlH)}

Multifactorial control of reproduction also involves other neurohormones such as gonadotropin inhibitory hormone $(\mathrm{GnlH})^{20}$. In fish, $\mathrm{GnlH}$ is expressed mainly in the brain and pi- 
tuitary, although its expression has also been evidenced in the spleen, gonads, muscle, eyes, and kidney ${ }^{119-122}$. GnlH acts by binding to $\mathrm{GnlH}$ receptors $(\mathrm{GnlH}-\mathrm{R})$ that belong to the family of $G$ protein-coupled receptors. Two GnlH-Rs (GPR147 and GPR74) have been identified in vertebrates, but only GPR147 appears to be present in fish ${ }^{122-124}$. GPR147 have been identified in fish's central and peripheral tissues, including the brain, pituitary, eyes, heart, intestine, kidney, liver, spleen, muscle, and gonads $^{125-127}$. As its name suggests, the main function of $\mathrm{GnlH}$ is the inhibition of gonadotropin release through the inhibition of $\mathrm{GnRH}$ and kisspeptin ${ }^{128,129}$, an action that has been described in many vertebrates. However, the physiological functions of $\mathrm{GnlH}$ in fish are not precise yet. Contradictory effects have been observed in fish, both in vivo ${ }^{130}$ and in vitro ${ }^{131}$ For example, administration of $\mathrm{GnlH}$ to pituitary cell cultures of mature female Nile tilapia increased LH and FSH mRNA levels ${ }^{18,130}$. It has been shown that in goldfish, $\mathrm{GnIH}$ inhibits both the synthesis and the release of gonadotropins in the early stages of gonadal maturation but not in spawning ${ }^{132}$. Administration of $\mathrm{GnIH}$ to zebrafish by intraperitoneal injection decreases plasma LH levels in adult goldfish ${ }^{125,132}$. However, the inhibitory effect of $\mathrm{Gn} / \mathrm{H}$ injections was not observed in juvenile stages ${ }^{132}$. In vitro studies showed that the administration of GnlH from goldfish stimulates the expression of gonadotropins in pufferfish with apparent seasonal differences in reproduction ${ }^{132,133}$. These findings indicate that, in teleosts, the physiological effect of $\mathrm{GnIH}$ on the HPG axis differs between gonadotropin synthesis and release and depends on the reproductive stage. Even though researchers have shown that $\mathrm{GnlH}$ exerts both stimulatory and inhibitory actions, depending on the season and species, both $\mathrm{GnRH}$ and $\mathrm{GnIH}$ are considered essential components of the multifactorial control of reproduction ${ }^{20}$.

\section{Gonadotropins (GtHs)}

In teleosts, as in all vertebrates, the functions of the gonads are maintained thanks to the actions of the gonadotropins. They have a central role in the regulation of gametogenesis ${ }^{134}$ and the steroidogenesis necessary for the development of sexual behavior and secondary sexual characteristics ${ }^{1,78,80,135}$. Gonadotrops are cells specialized in producing gonadotropins such as follicle-stimulating hormone (FSH) and luteinizing hormone (LH). Both are glycoproteins made up of two non-covalently associated subunits ( $a$ and $\beta$ ). The a subunit has 92 amino acids (aa) and is common in both gonadotropins. The $\beta$ subunit has 121 aa for $\mathrm{LH}$ and 118 aa for FSH. This subunit is specific for recognition by their cellular receptor and also confers biological activity 15,53,134,136. These hormones exert their effects by binding to $G$ protein-coupled surface receptors, called the $\mathrm{LH}$ receptor $(\mathrm{LH}-\mathrm{R})$ and the FSH receptor $(\mathrm{FSH}-\mathrm{R})^{134,137,138}$. Both receptors are mainly expressed in the gonads $^{139}$. In the ovary, LH-R is expressed in theca cells, luteal cells, and interstitial cells, regulating actions such as the synthesis of steroid hormones, ovulation, and the formation of the corpus luteum ${ }^{139}$. In the testicle, LH-R is expressed in Leydig cells, where it stimulates the synthesis of testosterone (T), a precursor hormone of testicular maturation via spermatogenesis.139 LH is related to the manifestation of secondary sexual characteristics in males, and its highest plasma levels are in the spermiation stage. In addition, it intervenes in the capture and incorporation of blood vitellogenin to the oocyte. In the final phase of oocyte maturation, LH levels increase, leading to the production of dihydroxyprogesterone (17a-20ß). The $17 a-20 \beta$ is involved in the haploid processes before ovulation and in sodium and potassium transport control ${ }^{139}$. For its part, FSH-R is expressed in the ovary, exclusively in granulosa cells. Its activation by the action of FSH contributes to follicular development and stimulates the synthesis of $17 \beta$ estradiol. The $17 \beta$ estradiol acts on the liver to initiate and maintain vitellogenin synthesis in oocytes and is involved in gonadal maturation processes.

Furthermore, FSH induces aromatase expression and thus modulates ovarian estrogen synthesis. On the other hand, in the testis, FSH-R is expressed in Sertoli cells ${ }^{139}$. In trout, plasma FSH increased at the beginning of oogenesis and in the initial phases of spermatogenesis ${ }^{140}$. Also, in Pacific salmon (Oncorhynchus tshawytscha), the levels of FSH remained high and declined immediately before ovulation and spermiation. In physiological studies carried out in this same species, FSH- $\beta$ expression levels increased during the initiation of gonadal growth and decreased in spawning ${ }^{141}$. These results coincide with Schulz et al. in $2001^{142}$, where they state that FSH is involved in the initial phases of gametogenesis, and LH mainly regulated the last stages of gonadal maturation. Previous studies have reported that FSH mRNA levels increased while LH mRNA decreased during the transition from female to male in Epinephelus merra. This was associated with testicular development and suggests that FSH could trigger sex change in this species ${ }^{143}$. In recent studies, the expression of LH- $\beta$ mRNA in the pituitary of carp (Cyprinus carpio) increased significantly during the maturation of the male; however, FSH- $\beta$ mRNA expression did not change significantly during development ${ }^{136}$. As published by Yaron et al. in $2003^{29}$, LH-<UNK> and FSH$<\mathrm{UNK}>$ gene expression levels of $\mathrm{LH}-\beta$ and $\mathrm{FSH}-\beta$ were very low in the juvenile stage of carp, while they increased during the ovulation period. In general terms, FSH mainly controls the first stages of spermatogenesis, and $\mathrm{LH}$ regulates testicular maturation, ovulation, and spermiation ${ }^{16,50-52}$.

\section{Growth hormone (GH)}

The growth hormone of teleost fish is a 21-23 kDa protein made up of a single polypeptide chain. Similar to what happens in mammals, $\mathrm{GH}$ in fish is produced by somatotropic cells in the anterior region of the pituitary gland ${ }^{144}$. Furthermore, its expression has been confirmed in other fish tissues, including the brain, liver, spleen, and gonads ${ }^{145,146}$. GH is an essential endocrine regulator in many physiological processes in vertebrates. In fish, it is involved in events such as somatic growth, energy metabolism, reproduction, appetite, the function of the immune system, and the regulation of ionic and osmotic balance $^{147,148}$. In addition, it influences aspects of behavior such as aggressiveness and the ability to avoid predators ${ }^{149}$. This hormone is released from the pituitary in response to hypothalamic signals and exerts its effects on target tissues ${ }^{148,150}$ binding to the GHR-I and GHRII receptors (hormone receptor growth I and II, respectively) ${ }^{148,149}$. Growth hormone receptors (GHRs) are members of the type I cytokine receptor family ${ }^{151}$. They have been identified in several fish species, such as turbot (Scopthalmus maximus) $^{146}$, salmon (Oncorhynchus masou) ${ }^{152}$, and Mozambique tilapia (Oreochromis mossambicus) ${ }^{153}$. These receptors are expressed in a wide variety of tissues, including the brain, pituitary, skin, heart, liver, gallbladder, intestine, adipose tissue, kidney, spleen, gonads, and muscle ${ }^{152-154}$. However, the primary expression is in the liver (or hepatopancreas), where GHRs have a significant role in regulating somatic growth ${ }^{148}$. $\mathrm{GH}$ binds to its specific receptors in the liver and promotes the release of insulin-like growth factor-I and II (IGF-I and IGF-II), whose primary function is to mediate and increase the growth-promoting function of $\mathrm{GH}^{155}$. IGF-I is involved in reproduc- 
tion and particularly in mediating the effects of $\mathrm{GH}$ on somatic growth ${ }^{154}$. Furthermore, it has been associated with fish metabolism, development, reproduction and osmoregulation ${ }^{148,150}$. In the case of IGF-II, its mRNA has been detected in the liver and the brain, heart, kidney, gills, gastrointestinal tract, pancreatic islets, skeletal muscle, and gonads of fish ${ }^{150}$. This transcript is expressed in juvenile and adult fish, contrary to what has been reported for mammals where its expression occurs only during the early stages of development ${ }^{156}$. GH exerts a lipolytic and anabolic function. The lipolytic action is independent of IGFs and facilitates fats as an energy source in catabolic and malnutrition states ${ }^{157}$. The anabolic action of $\mathrm{GH}$ is related to protein metabolism and is mediated by IGFs ${ }^{157}$. The biological functions of IGFs are mediated by binding to specific transmembrane receptors, present in both fish and mammals.

In sexually mature ovaries of Nile tilapia, high levels of mRNA of both GHRs were detected. While in testes of this same species, the highest levels were observed after the stage of sexual maturation ${ }^{148}$. Changes in the expression of IGFs in the gonads and the neuroendocrine regulation of $\mathrm{GnRH}, \mathrm{GnlH}$, FSH, LH, GH and the GH / IGF system have been associated with promoting testicular steroidogenesis. They also have a significant influence on the oocyte maturation processes in several species ${ }^{154,156,158,160}$. Taken together, these observations suggest that $\mathrm{GH}, \mathrm{IGFs}$, and gonads are closely related and involved in controlling reproductive function.

\section{Prolactin (PRL)}

$\mathrm{PRL}$ is synthesized mainly by the lactotrophic or PRL-secreting cells found in the pituitary ${ }^{160,161}$. It has a variable length (between 170 and 205 amino acids (aa) depending on the species, with signal peptides of 23-24 aa. Two isoforms have been found in teleosts (PRL188 and PRL177), with different biological activities ${ }^{83}$. Prolactin is generally produced at high levels in pituitary tissues; however, its expression has been evidenced in other tissues such as the liver, intestine, gonads, gills, kidney, spleen, brain, and muscle ${ }^{162,163}$. Plasma PRL levels in Nile tilapia are increased during maternal behavior, suggesting hormonal control ${ }^{164}$. Other studies indicate that PRL mRNA levels and mature protein have been found in the gonads of different fish species, including Mozambique tilapia ${ }^{167}$, Nile tilapia ${ }^{165}$, goldfish $^{162,166}$, and rainbow trout (Oncorhynchus mykiss) ${ }^{166}$. This suggests that PRL may be involved in spermatogenesis, vitellogenesis, and ovulation. However, no significant differences were found in PRL mRNA levels during sexual maturation of Japanese eels through in vitro studies by Ozaki et al. in $2007^{168}$ According to Onuma et al. in $2010^{169}$, in salmon, the levels of PRL mRNA and gonadotropins significantly were increased in the stage of maturation and gonadal development, which suggests that these hormones may be associated with the development of the reproductive system. In addition, PRL levels seem to be involved in many more functions such as developing reproductive cycles, incubation behavior, or feeding the fry ${ }^{170,171}$. It has also been shown to stimulate steroidogenesis in the ovaries and testes and increase their mRNA and plasma levels during sexual maturation in salmonids and tilapia ${ }^{153,166}$. The regulation of PRL synthesis and release into the pituitary is known to be influenced by hypothalamic neurohormones, sex steroids, and plasma factors from other tissues ${ }^{171}$. It is proposed that this hormone can act in an autocrine or paracrine manner and represents an exciting area for future research ${ }^{171,172}$.

\section{Thyroid hormones (HTs)}

Thyroid hormones (HTs) are involved in various biological events in fish, such as regulating metabolism, growth, development, and reproduction, among others ${ }^{173-177}$. HTs (T3 and T4) are found in two forms in the blood: free and bound to transporter proteins. Less than $1 \%$ is in the free form and therefore easily accessible to target cells ${ }^{178}$. The secretion of HTs is under the control of the hypothalamic-pituitary-thyroid axis

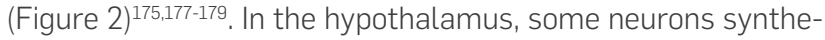
size, transport, and release various factors that stimulate or inhibit the release of HTs to the neurohypophysis. Among the stimulatory factors are thyrotropin-releasing hormone (TRH) and the inhibitors Somatostatin and TSH inhibitory factors. Thyroid-stimulating hormone (TSH) is released to the bloodstream, where it reaches the thyroid gland and stimulates the synthesis and release of the two HTs (T3 and T4) into the blood $^{178,179}$. These hormones are lipidic, so they can cross the plasma membrane and reach the cytoplasm. T4 is secreted under normal conditions, while T3, known as the active hormone, is produced mainly from the conversion of T4 to T3. Two enzymes catalyze this process with deiodase activity ( $\mathrm{DIO}$ and DIO2) ${ }^{180}$. T3 crosses the nuclear membrane to interact with its THR $\mathrm{a}$ and THR $\beta$ receptors in the nucleus.

Once the hormone-receptor complex is formed, there is a self-regulation of the expression of the genes (THRa and THR $\beta$ ) that code for the THR $a$ and THR $\beta$ receptors ${ }^{177,179}$. Some of the first studies in fish was carried out in Pacific salmon, Atlantic salmon (Salmo salar), and striped bass (Morone saxalitis), where it was evidenced that the thyroid hormones T3 and $\mathrm{T} 4$ are transferred from the mother to the egg and are used during the absorption of the yolk sac in the larval period, to later be synthesized by the larva in the exogenous feeding period $^{181}$. In salmon, the increase in plasma T4 levels has been seen in the early stages of gonadal maturation but decreases as vitellogenesis and testicular maturation occur ${ }^{182}$. In stellate sturgeon (Acipenser stellatus), high thyroid activity occurs in conjunction with gonadal maturation during preponderance migration and at spawning. In salmonids, the increase in T3 was related to vitellogenesis or the last stages of oocyte development ${ }^{12,179}$. In vitro and in vivo studies have shown that T3 treatments caused a decrease in LH mRNA levels in goldfish $^{183,184}$. In other trials, T3 administrations in carp increased vitellogenin mRNA (Vtg) levels in the liver, a critical factor in gonadal maturation ${ }^{185}$. However, T3 treatment decreased the expression of estrogen receptors in golden carp testes ${ }^{176}$. In zebrafish, the administration of T3 stimulated the proliferation of Sertoli cells and spermatogonia in the testes ${ }^{186}$. In general, the effects of HTs on reproductive function are species depen$\operatorname{dent}^{187,188}$.

\section{Gonadal development in females and males}

Reproductive processes in teleost fish include puberty, spermatogenesis, spawning, and cellular processes such as steroidogenesis $^{16}$. The gonads have the enzymes necessary for the synthesis of steroids and their transformation into a whole series of intermediaries involved in the different phases of reproduction. They produce three types of steroids necessary for reproduction: estrogens or $\mathrm{C} 18$ steroids, androgens or $\mathrm{C} 19$ steroids, and progestogens or C21 steroids ${ }^{189}$. Gonadal steroids exert their actions on target tissues by binding to specific intracellular receptors since, thanks to their lipophilic nature, they easily penetrate and diffuse within the cell ${ }^{190,191}$. In teleost testes, the synthesis of steroid (androgenic) hormones takes place in Leydig cells. Testosterone (T) is mainly synthesized and, to a lesser extent, 17a-hydroxy-4-pregnen-3-one (DHT), Androstenedione, and 11-ketotestosterone $(11-\mathrm{KT})^{192}$. T is es- 


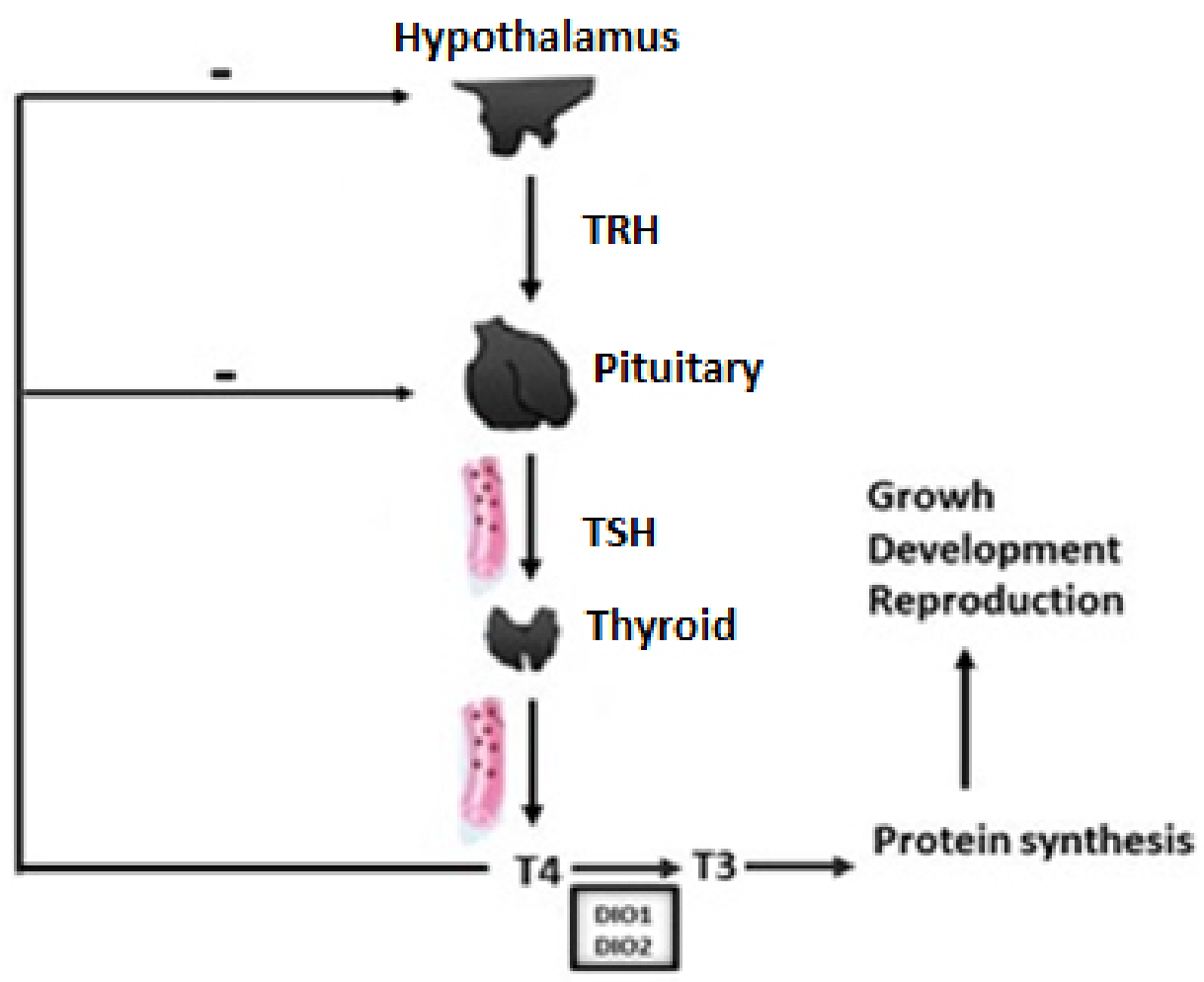

Figure 2. Hypothalamic-Pituitary-Thyroid Axis (HPT). Thyrotropin Releasing Hormone (TRH); Thyroid-stimulating hormone (TSH); Triiodothyronine (T3); Tetraiodothyronine (T4); Enzymes with deiodinase activity (DIO1 and DIO2).

sential in the spermatogenic process and has great importance in female reproductive processes since it acts as a precursor of estrogen biosynthesis. 11-KT is a critical factor in the maturation of gametes, the development of secondary sexual characteristics, and reproductive behavior ${ }^{193-196}$. Spermatogenesis depends on the action of gonadotropins, and their binding mediates this function to their receptors in the gonads. Once this union occurs, the synthesis and secretion route of different sex steroids is activated ${ }^{197}$.

In oogenesis, hormones of a steroid and peptide nature are synthesized, which are essential for regulating the reproductive axis in females ${ }^{53}$. The oocyte maturation process occurs within the ovarian follicles and is produced mainly $17 \beta$-estradiol $\left(E_{2}\right)$. According to Nagahama and Yamashita in 2008198, in teleost fish, there are three essential regulators of oocyte maturation: Gonadotropins, maturation inducing hormone $(\mathrm{MIH})$, and maturation promoting factor (MPF). Before oocyte maturation, a change in the steroidogenic pathway from $E_{2}$ to DHP occurs in ovarian follicles ${ }^{199}$. This change during ovarian development is regulated mainly by changes in the availability of steroidogenic enzymes ${ }^{198}$. MIH activates MPF and triggers a series of changes associated with oocyte maturation.

One of the most critical processes for the maturation of the oocyte is vitellogenesis. Its principal function is the sequestration and packaging of vitellogenin $(\mathrm{Vtg})$ and the absorption of very-low-density lipoproteins $200,201 . V \operatorname{tg}$ is synthesized in the liver and is specific to maturing females (Devlin and Nagahama, 2002). The growing ovarian follicles selectively sequester this through specific receptors (VtgRs) that give rise to the formation of Vtg-coated vesicles ${ }^{202}$. Vesicles fuse with lysosomes leads to the formation of multivesicular bodies (MVB). During vitellogenesis, gonadotropins stimulate the production of Testosterone ( $T$ ) by theca cells, and subsequently, it is aromatized to $17-\beta$ estradiol $\left(E_{2}\right)$ in the granulosa cells of the ovarian follicle. In response to this stimulation, plasma $\mathrm{E}_{2}$ levels increase, which stimulates the production of Vtg in the liver, which is recognized by $\mathrm{VtgR}$ and incorporated by the oocyte through micropinocytosis (Figure 3$)^{1,27}$. At the end of vitellogenesis, plasma LH levels increase, and in turn, E2 levels decrease. This results in a transient increase in plasma levels of $T$ and maturation-inducing steroids (MIS), which act at the follicular layers' level to induce the oocyte's final maturation ${ }^{1}$. After the rupture of the follicle, the oocyte is released, in a process called ovulation ${ }^{196}$. Once ovulation occurs, follicular cells undergo morphological changes that lead to the secretion of progesterone $(P)$ and $E_{2}^{190,203}$. In general, both vitellogenesis and the final maturation of the oocyte are crucial events in the reproductive physiology of females.

Another group of steroid hormones such as corticosteroids, which are usually related to stress, play an essential regulatory role in other physiological processes ${ }^{196}$. In teleost fish, corticosteroids are mainly synthesized in the inter-renal tissue, specifically the head kidney. Plasma corticosteroid concentrations in fish depend on species, sex, and reproductive status ${ }^{204}$. Plasma levels of corticosteroids vary significantly throughout the reproductive cycle. For both females and males, some species contain high cortisol levels in plasma during the pre-spawning period, such as the rainbow trout ${ }^{205}$, perch (Perca fluviatilis) $^{206}$, and masu salmon ${ }^{207}$. In general, steroid hormones play a fundamental role in controlling the reproductive function of teleost fish. These present direct or feedback effects through different hormonal cascades on reproductive functions in fish and constitute critical factors in the regulation of the HPG axis ${ }^{196}$. The gonadal maturation process in fish is highly complex since it includes the production, maturation, release of gametes, synthesis of hormones, and sexual behavior, which requires a large amount of available energy ${ }^{208}$. Although the role of energy in sexual maturation and reproduction has been evidenced. There are still gaps in the knowledge about the influence of metabolic and nutritional status on the regulation of gonadal function in fish ${ }^{16}$. 


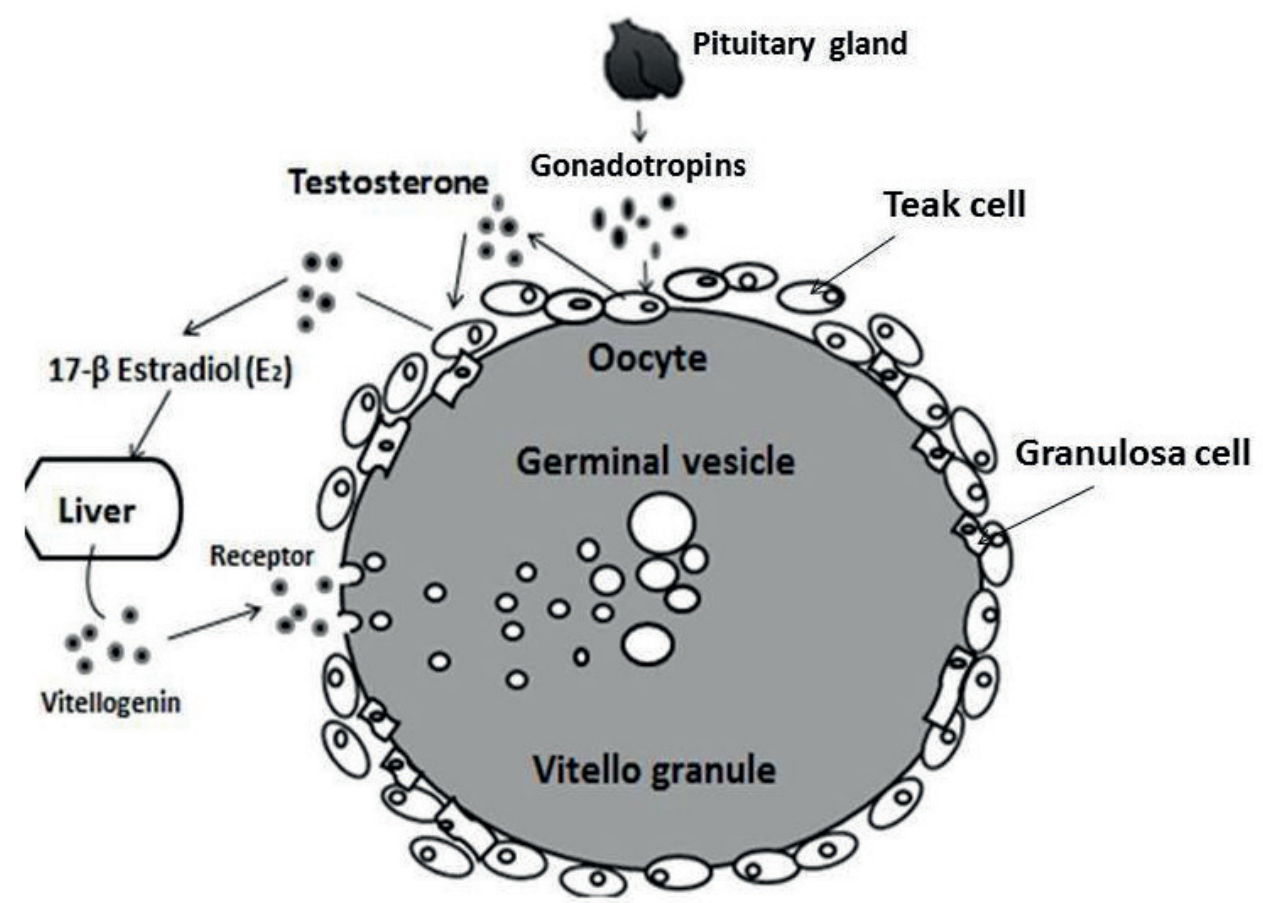

Figure 3. Hormonal regulation of vitellogenesis in teleost fish.

\section{Conclusions}

In this review, the fundamental aspects involved in controlling the reproductive function of teleost fish were addressed. The role of hormonal and neuroendocrine regulation of these species is described, which guarantees the proper functioning of the physiological machinery in reproductive events. The hypothalamic and pituitary hormones involved in reproduction in fish point to the immense complexity of endocrine regulation of reproductive processes. A brief overview of the integrative role of some neuropeptides in the regulation of feeding, metabolism, growth, and reproduction was also shown. However, especially in fish, knowledge about these integrative functions of regulatory peptides is not well studied.

\section{Bibliographic references}

1. Zohar Y and Mylonas CC. Endocrine manipulations of spawning in cultured fish: from hormones to genes. Aquaculture 2001; 197:99-136

2. Reid GK, Helen J, Gurney-Smith, Flaherty M, Garber AF, Forster I, et al. Climate change and aquaculture: considering adaptation potential. Aquaculture Environ Interact 2019; 11: 603-624.

3. NRC. Nutrient requirements of fish and shrimp. The National Academies Press, Washington, D.C. 2011; 228.

4. Pohlenz C, Delbert M, Gatlin III. Interrelationships between fish nutrition and health. Aquaculture 2014; 431:111-117.

5. Bruce A. Stress in Fishes: A Diversity of Responses with Particular Reference to Changes in Circulating Corticosteroids. Integrative and Comparative Biology 2002; 42(3):517-525.

6. McCornick S, O'Dea M, Moeckel A, Thrandur B. Endocrine and physiological changes in Atlantic salmon smolts following hatchery release. Aquaculture 2003; 222:45-57.

7. Mancera JM and Cormick S. Role of Prolactin, Growth Hormone, Insulin-like Growth Factor I and Cortisol in Teleost Osmoregulation In: Fish Osmoregulation. Ed. B.G. Kapoor, Science Publishers 2007; p 497-515.

8. Subhash M. The role of thyroid hormones in stress response of fish. Gen Comp Endocrinol 2011; 172:198-210.

9. Fregeneda-Grandes J, Hernandez-Navarro S, Fernandez-Coppe I, Correa-Guimaraes A, Ruíz-Potosme N, Navas-Gracia L, et al. Seasonal and sex related variations in serum steroid hormone level in wild and farmed Brown trout Salmo trutta L.in the north-west of Spain. J Water and health 2013; 11:720-728

10. Manlik O. The importance of Reproduction for Conservation of Slow-Growing animal populations. Reproductive Sciences in Animal Conservation 2019; 13-39.

11. Solar I. Biotecnología aplicada a la acuicultura. Aquanoticias Internacional N 66, 2002; Pp 6-10.

12. Mylonas C, Fostier Al, Zanuy S. Broodstock management and hormonal manipulations of fish reproduction. Gen Comp Endocrinol. 2010; 165:516-534.

13. Valdebenito. Hormone therapy for the artificial control of sexual maturity in fish culture: a review. Arch Med 2008; Vol 40:115-123.

14. Shahjahan M, Kitahashi T, Parhar IS, Davenport AP and Bonner T. Central Pathways Integrating Metabolism and Reproduction in Teleosts. Frontiers in Endocrinology 2014; DOI: 10.3389/fendo.2014.00036.

15. Levavi-Sivan B, Bogerd J, Mañanós EL, Gómez A, Lareyre JJ. Perspectives on fish gonadotropins and their receptors. Gen Comp Endocrinol 2010; 165:412-437. 
16. Hatef A and Unniappan S. Metabolic hormones and the regulation of spermatogenesis in fishes. Theriogenology 2019; 134:121-128.

17. Unniappan S. Ghrelin: an emerging player in the regulation of reproduction in non-mammalian vertebrates. General and comparative endocrinology 2010; 167(3):340-343.

18. London S and Volkoff H. Effects of fasting on the central expression of appetite-regulating and reproductive hormones in wildtype and Casper zebrafish (Danio rerio). General and Comparative Endocrinology 2019; 282:113-207.

19. Biran J, Levavi-Sivan B. Endocrine Control of Reproduction. Fish 2018; 6:362-368

20. Ma Y, Ladisaa C, Changa JP, Habibi HR. Multifactorial control of reproductive and growth axis in male goldfish: Influences of $\mathrm{GnRH}, \mathrm{GnIH}$ and thyroid hormone. Molecular and Cellular Endocrinology 2020; 500:110-629.

21. Weltzien FA, Andersson E, Andersen Ø, Shalchian-Tabrizi K, Norberg B. The brain-pituitary-gonad axis in male teleosts, with emphasis on the flatfish (Pleuronectiformes). Comp Biochem Physiol 2004; 137:447-477.

22. Peter RE, Yu KL. Neuroendocrine regulation of ovulation in fishes: basic and applied aspects. Rev Fish Biol Fisher 1997; 7:173-197.

23. Okuzawa K. Puberty in teleosts. Fish Physiol Biochem 2002; 26(1):31-41.

24. Jalabert B. Particularities of reproduction and oogenesis in teleost fish compared to mammals. Reprod Nutr 2005; 45:261-279.

25. Taranger GL, Carrillo M, Schulz RW, Fontaine P, Zanuy S, Felip A, et al. control of puberty in farmed fish. Gen Comp Endocrinol. 2010; 165(3):483-515.

26. Cueto JM. Control Hormonal de la Reproducción en Peces. Universidad de Cádiz, Departamento de Biología (Facultad de Ciencias del Mar y Ambientales) 2016.

27. Schulz RW, De Franca, Lareyre LR, LeGac JJ, Garcia CF, Nobrega $\mathrm{H}$, et al. Spermatogenesis in fish. Gen. Comp. Endocrinol 2010; 165:390-411.

28. Riley LG, Hirano T, Grau EG. Rat Ghrelin Stimulates Growth Hormone and Prolactin Release in the Tilapia, Oreochromis mossambicus. Zoological science 2002; 19:797-800.

29. Yaron Z, Gur G, Melamed P, Rosenfeld H, Elizur A, Levavi-Sivan B. Regulation of fish gonadotropins. International Review of Cytology 2003; 225:131-185.

30.Aizen J, Harel J, Levavi-Sivan B. Development of specific enzyme-linked immunosorbent assay for determining $\mathrm{LH}$ and FSH levels in tilapia, using recombinant gonadotropins. Gen Comp Endocrinol 2007; 153:323-332.

31. Gahete MD, Durán-Prado M, Luque RM, Martínez-Fuentes AJ, Quintero A, Gutiérrez-Pascual E, et al. Understanding the multifactorial control of growth hormone release by somatotropes: lessons from comparative endocrinology. Ann. N. Y. Acad. Sci 2009; 1163:137-153.

32. Li W, Lin H. The endocrine regulation network of growth hormone synthesis and secretion in fish: Emphasis on the signal integration in somatotropes. Sci. China Life Sci 2010; 53:462-470.

33. Dai X, Zhang W, Zhuo Z, He J, Yin Z. Neuroendocrine regulation of somatic growth in fishes. Sci. China Life Sci 2015; 58:137-147.

34.Parhar IS, Ogawa S, Ubuka T. Reproductive neuroendocrine pathways of social behavior. Front Endocrinol 2016; 7:28

35. Albaa G, Michele N, Mouradb N, Paredesa JF, Vázqueza SFJ, Olmedaa JFL. Daily rhythms in the reproductive axis of Nile tilapia (Oreochromis niloticus): Plasma steroids and gene expression in brain, pituitary, gonad and egg. Aquaculture 2019; 507:313-321.

36. Muñoz-Cueto, JA., Zmora N, Paullada-Salmerón JA, Marvel M, Mañanos E, \& Zohar $Y$. The gonadotropin-releasing hormones: lessons from fish. General and comparative endocrinology 2020; 291: 113-422.

37. Chang JP, Mar A, Wlasichuk M, Wong AOL. Kisspeptin-1 directly stimulates $\mathrm{LH}$ and $\mathrm{GH}$ secretion from goldfish pituitary cells in a Ca (2+) dependent manner. Gen Comp Endocrinol 2012; 179:3846.

38. Topaloglu AK, Kotan LD. Molecular causes of hypogonadotropic hypogonadism. Curr Opin Obstet Gynecol 2010; 22:264-70.
39. Pinilla L, Aguilar E, Dieguez C, Millar RP, Tena-Sempere M. Kisspeptins and reproduction: physiological roles and regulatory mechanisms. Physiol Rev 2012; 92:1235-316.

40.Parhar I, Ogawa S, Kitahashi T. RF-amide peptides as mediators in environmental control of GnRH neurons. Prog Neurobiol 2012; 98:176-96.

41. Mizrahi N, Gilon C, Atre I, Ogawa S, Ishwar S, Parhar et al. Deciphering Direct and Indirect Effects of Neurokinin B and GnRH in the Brain-Pituitary Axis of Tilapia. Frontiers in Endocrinology 2019; Vol 10 Article 469. doi: 10.3389/fendo.2019.00469.

42.Rajeswari JJ, Blanco A M, \& Unniappan S. Phoenixin-20 suppresses food intake, modulates glucoregulatory enzymes, and enhances glycolysis in zebrafish. American Journal of Physiology-Regulatory, Integrative and Comparative Physiology 2020; 318(5):917-928.

43.Schalla MA, \& Stengel, A. Phoenixin A pleiotropic gut-Brain peptide. International journal of molecular sciences 2018; 19(6):1726.

44.Yosten GL, Lyu RM., Hsueh AJ, Avsian 囚Kretchmer O, Chang JK, Tullock CW\& Samson, WK. A novel reproductive peptide, phoenixin. Journal of neuroendocrinology 2013; 25(2):206-215.

45.Wang M, Chen HP, Zhai Y, Jiang DN, Liu JY, Tian CX, \& Li GL. Phoenixin: Expression at different ovarian development stages and effects on genes ralated to reproduction in spotted scat, Scatophagus argus. Comparative Biochemistry and Physiology Part B: Biochemistry and Molecular Biology 2019; 228:17-25.

46.Prinz P, Scharner S, Friedrich T, Schalla M, Goebel-Stengel M, Rose $M$, et al. Central and peripheral expression sites of phoenixin-14 immunoreactivity in rats. Biochem Biophysical Res Comm 2017; 493: 195-201.

47. Yuan T, Sun Z, Zhao W, Wang T, Zhang J, Niu D. Phoenixin: a newly discovered peptide with multi-functions. Protein Pept Lett 2017; 24: 472-5.

48. Yaron Z, Gur G, Melamed P, Rosenfeld H, Elizur A, Levavi-Sivan B. Regulation of fish gonadotropins. Int Rev Cytol 2003; 225:131-185.

49. Kim DK, Cho EB, Luna MJ, Parque S, Hwang JI, Kah O, et al. Revisiting the evolution of gonadotropin-releasing hormones and their receptors in vertebrates: Secrets hidden in genomes. Gen Comp Endocrinol 2011; 170:68-78.

50.Zanuy S, Carrillo M. La reproducción de los peces teleósteos y su aplicación en acuicultura. En: Espinosa de los Monteros J, Labarta U (eds). Reproducción en acuicultura. CAICYT. Madrid, España, 1987, Pp 1-131.

51. Luckenbach JA, Iliev DB, Goetz FW, Swanson P. Identification of differentially expressed ovarian genes during primary and early secondary oocyte growth in coho salmon, Oncorhynchus kisutch. Reprod Biol Endocrinol 2008; 6-2.

52.Zanuy S, Carrillo M, Rocha A, Molés G. II Regulación y control hormonal del proceso reproductor de los teleósteos. En: Carrillo M, Espinosa de los Monteros J (eds). La reproducción de los peces: aspectos básicos y sus aplicaciones en acuicultura. OESA, CSIC, MMAMRN, Madrid, España 2009; 97-172.

53. Falcone TH. Ovarian Hormones: Structure, Biosynthesis, Function, Mechanism of Action, and Laboratory Diagnosis in Clinical reproductive medicine and surgery. Springer 2013; 15-44.

54.Feng K, Luo HR, Hou MG, Li YM, Chen J, Zh, ZY, et al. Alternative splicing of $\mathrm{GnRH} 2$, and $\mathrm{GnRH} 2$-associated peptide plays roles in gonadal differentiation of the rice field eel, Monopterus albus. Gen. Comp. Endocrine 2018.

55. Kah O, Lethimonier C, Somoza G, Guilgur LG, Vaillant C, and Lareyre JJ. GnRH and GnRH receptors in metazoa: a historical, comparative and evolutive perspective. Gen. Comp. Endocrinol 2007; 153:346-364.

56. Okubo K, Nagahama Y. Structural and functional evolution of gonadotropin releasing hormone in vertebrates. Acta Physiol 2008; 193:3-15.

57. Zohar Y, Muñoz-Cueto JA, Elizur A, Kah O. Neuroendocrinology of reproduction in teleost fish. Gen Comp Endocrinol 2010; 165:438-455.

58. Ma Y, Ladisaa C, Changa JP, Habibia HR. Multifactorial control of reproductive and growth axis in male goldfish: Influences of $\mathrm{GnRH}, \mathrm{GnIH}$ and thyroid hormone. Molecular and Cellular Endocrinology 2020; 110-629. 
59. Burgus R, Butcher M, Amoss M, Ling N, Monahan M, Rivier J et al. Primary structure of the ovine hypothalamic luteinizing hormone releasing factor (LRF) (LH-hypothalamus-LRF-gas chromatography-mass spectrometry decapeptide-Edman degradation). Proc Natl Acad Sci USA 1972; 69:278-282

60.Klausen C, Chang JP, Habibi HR. Time- and dose-related effects of gonadotropin- releasing hormone on growth hormone and gonadotropin subunit gene expression in the goldfish pituitary. Can J Physiol Pharmacol 2003; 80:915-924.

61. Chang JP, Pemberton JG. Comparative aspects of GnRH-Stimulated signal transduction in the vertebrate pituitary-contributions from teleost model systems. Mol Cell Endocrinol 2018; 463:142167.

62. Somoza GM, Mechaly AS, Trudeau VL. Kisspeptin and GnRH interactions in the reproductive brain of teleosts, General and Comparative Endocrinology 2020.

63. Choi D. Evolutionary viewpoint on GnRH (gonadotropin-releasing hormone) in chordata amino acid and nucleic acid sequences. Dev. Reprod 2018; 22:119-132.

64.Parhar IS, Tosaki H, Sakuma Y, Kobayashi M. Sex differences in the brain of goldfish: gonadotropin-releasing hormone and vasotocinergic neurons. Neuroscience 2001; 104(4):1099-110.

65. Whitlock KE, Postlethwait $J$ and Ewer J. Neuroendocrinology of reproduction: Is gonadotropin-releasing hormone $(\mathrm{GnRH})$ dispensable? Frontiers in Neuroendocrinology 2019; 53, Article 100738

66. Sherwood N, Eiden L, Brownstein M, Spiess J, Rivier J, Vale W. Characterization of a teleost gonadotropin-releasing hormone. Proc Natl Acad Sci. USA. 1983; 80(9):2794-2798

67. Hildahl J, Sandvik GK, Edvardsen RB, Fagernes C, Norberg B, Haug TM et al. Identification and gene expression analysis of three $\mathrm{GnRH}$ genes in female Atlantic cod during puberty provides insight into $\mathrm{GnRH}$ variant gene loss in fish. Gen Comp Endocrinol 2011; 172:458-467

68. Schneider JS, Rissman EF. Gonadotropin-releasing hormone II: a multi-purpose neuropeptide. Integr Comp Biol 2008; 48:588-595.

69. Matsuda K, Nakamura K, Shimakura S, Miura T, Kageyama H, Uchiyama $\mathrm{M}$, et al. Inhibitory effect of chicken gonadotropin-releasing hormone II on food intake in the goldfish, Carassius auratus. Horm. Behav 2008; 54:83-89.

70. Nishiguchi R, Azuma M, Yokobori E, Uchiyama M, Matsuda K. Gonadotropin-releasing hormone 2 suppresses food intake in the zebrafish, Danio rerio. Front. Endocrinology 2012; 3-122.

71. Xia W, Smith O, Zmora N, Xu S, Zohar Y. Comprehensive analysis of GnRH2 neuronal projections in zebrafish. Sci Rep 2014; 4:36-76

72. Marvel MM, Spicer OS, Wong TT, Zmora N, Zohar Y. Knockout of Gnrh2 in zebrafish (Danio rerio) reveals its roles in regulating feeding behavior and oocyte quality. Gen. Comp Endocrinol 2019; 280:15-23.

73. Blanco AM. Hypothalamic and pituitary-derived growth and reproductive hormones and the control of energy balance in fish General and Comparative Endocrinology 2020; doi: https://doi. org/ 10.1016/j.ygcen.2019.113322.

74. Forlano PM, Bass AH. Neural and hormonal mechanisms of reproductive-related arousal in fishes. Horm. Behav 2011. 59:616-629.

75. Abraham E, Palevitch O, Gothilf Y, Zohar Y. Targeted gonadotropin-releasing hormone-3 neuron ablation in zebrafish: effects on neurogenesis, neuronal migration, and reproduction. Endocrinology 2010; 151(1):332-340.

76. Palevitch O, Kight K, Abraham E, Wray S, Zohar Y, Gothilf Y. Ontogeny of the GnRH systems in zebrafish brain: in situ hybridization and promoter-reporter expression analyses in intact animals. Cell Tissue Res 2007; 327(2):313-322.

77. Lethimonier C, Madigou T, Munoz-Cueto JA, Lareyre JJ, Kah O. Evolutionary aspects of $\mathrm{GnRHs}, \mathrm{GnRH}$ neuronal systems and $\mathrm{GnRH}$ receptors in teleost fish. Gen Comp Endocrinol 2004 135(1):1-16

78. Clarke IJ, Cummins JT. The temporal relationship between gonadotropin releasing hormone $(\mathrm{GnRH})$ and luteinizing hormone (LH) secretion in ovariectomized ewes. Endocrinology 1982; 111(5):1737-1739
79. Millar RP. GnRHs and GnRH receptors. Animal Reproduction Science 2005; 88(1), 5-28.

80. Bedecarrats GY. Control of the reproductive axis: Balancing act between stimulatory and inhibitory inputs. Poult Sci 2015; 94 (4):810-815

81. Kanda S. Evolution of the regulatory mechanisms for the hypothalamic-pituitary-gonadal axis in vertebrates-hypothesis from a comparative view. General and comparative endocrinology 2019; 194:300-310.

82. Weber GM, Powell JF, Park M, Fischer WH, Craig AG., Rivier, et al. evidence that gonadotropin-releasing hormone $(\mathrm{GnRH})$ functions as a prolactin-releasing factor in a teleost fish (Oreochromis mossambicus) and primary structures for three native $\mathrm{GnRH}$ molecules. J. Endocrinol 1997; 155:121-132.

83. Seale P. Endocrine regulation of prolactin cell function and modulation of osmoreception in the Mozambique tilapia. Gen. Comp. Endocrinol 2013; 192: 191-203.

84. Kitahashi T, Ogawa S, Parhar IS. Cloning and expression of kiss 2 in the zebrafish and medaka. Endocrinology 2009; 150(2):821-831.

85. Ogawa S, Ramadasan PN, Goschorska M, Anantharajah A, Parhar IS. Cloning and expression of tachykinins and their association with kisspeptins in the brains of zebrafish. J Comp Neurol 2012; 520(13):2991-3012.

86. London $\mathrm{S}$ and Volkoff H. Effects of fasting on the central expression of appetite-regulating and reproductive hormones in wildtype and Casper zebrafish (Danio rerio). General and Comparative Endocrinology 2019; 282:113-207.

87. Shahjahan M, Motohashi E, Doi H, Ando H. Elevation of Kiss2 and its receptor gene expression in the brain and pituitary of grass puffer during the spawning season. Gen. Comp Endocrinol 2010; 169:48-57.

88. Escobar S, Felip A, Gueguen MM, Zanuy S, Carrillo M, Kah O, et al. expression of kisspeptins in the brain and pituitary of the European sea bass (Dicentrarchus labrax). J Comp Neurol 2013; 521:933-948.

89. Franceschini I, Lomet D, Cateau M, Delsol G, Tillet Y, Caraty A. Kisspeptin immunoreactive cells of the ovine preoptic area and arcuate nucleus co-express estrogen receptor alpha. Neurosci. Lett 2006; 401:225-230.

90.Pompolo S, Pereira A, Estrada KM, Clarke IJ. Colocalization of kisspeptin and gonadotropin-releasing hormone in the ovine brain. Endocrinology 2006; 147:804-810.

91. Ohga H, Adachi H, Matsumori K, Kodama R, Nyuji M, Selvaraj S, et al. mRNA levels of kisspeptins, kisspeptin receptors, and $\mathrm{GnRH} 1$ in the brain of chub mackerel during puberty. Comparative Biochemistry and Physiology 2015; Part A 179:104-112.

92. Selvaraj S, Kitano H, Fujinaga Y, Ohga H, Yoneda M, Yamaguchi, et al. Molecular characterization, tissue distribution, and mRNA expression profiles of two kiss genes in the adult male and female chub mackerel (Scomber japonicus) during different gonadal stages. Gen Comp Endocrinol 2010: 169:28 38.

93. Ohga H, Selvaraj S, Matsuyama M. The roles of kisspeptin system in the reproductive physiology of fish with special reference to chub mackerel studies as main axis. Front. Endocrinol 2018; 9:147.

94. Servili A, Le Page, Leprince Y, Caraty J, Escobar A, Parhar S, et al. Organization of two independent kisspeptin systems derived from evolutionary-ancient kiss genes in the brain of zebrafish. Endocrinology 2011; 152:1527-1540.

95. Felip A, Zanuy S, Pineda R, Pinilla L, Carrillo M, Tena-Sempere M, et al. evidence for two distinct Kiss genes in non-placental vertebrates that encode kisspeptins with different gonadotropin-releasing activities in fish and mammals. Mol Cell Endocrinol 2009; 312:61-71.

96. Mechaly AS, Viñas J, Piferrer F. Gene structure analysis of kisspeptin-2 (Kiss2) in the Senegalese sole (Solea senegalensis): characterization of two splice variants of Kiss2, and novel evidence for metabolic regulation of kisspeptin signaling in non-mammalian species. Mol Cell Endocrinol 2011; 339:14-24.

97. Biran J, Ben-Dor S, Levavi-Sivan B. Molecular identification and functional characterization of the kisspeptin/kisspeptin receptor system in lower vertebrates. Biol Reprod 2008; 79:776-786. 
98. Van Aerle R, Kille P, Lange A, Tyler CR. Evidence for the existence of a functional Kiss1/Kiss1 receptor pathway in fish. Peptides 2008; 29:57-64.

99. ang B, Jiang Q, Chan T, Ko WK, Wong AO. Goldfish kisspeptin: molecular cloning, tissue distribution of transcript expression, and stimulatory effects on prolactin, growth hormone and luteinizing hormone secretion and gene expression via direct actions at the pituitary level. Gen Comp Endocrinol 2010; 165:60-71.

100. Pasquier, J., Kamech, N., Lafont, A. G., Vaudry, H., Rousseau, K., \& Dufour, S. Kisspeptin/kisspeptin receptors. J Mol Endocrinol 2014; 52:101-117.

101. Mechaly AS, Vinas J, Piferrer F. The kisspeptin system genes in teleost fish, their structure and regulation, with particular attention to the situation in Pleuronectiformes. Gen Comp Endocrinol 2013; 188:258-268.

102. Li S, Zhang Y, Liu Y, Huang X, Huang W, Lu D, Zhu P et al. Structural and functional multiplicity of the kisspeptin/GPR54 system in goldfish (Carassius auratus). Journal of Endocrinology 2009: 201:407-418.

103. Lee YR, Tsunekawa K, Moon MJ, Um HN, Hwang Jl, Osugi T, Otaki N, et al. Molecular evolution of multiple forms of kisspeptins and GPR54 receptors in vertebrates. Endocrinology 2009, 150:2837-2846.

104. Pasquier J, Lafont AG, Jeng SR, Morini M, Dirks R, Van den Thillart G, Tomkiewicz et al. Multiple kisspeptin receptors in early osteichthyans provide new insights into the evolution of this receptor family. PLoS ONE 2012; 7 e48931.

105. Elizur A. The KiSS1/GPR54 system in fish. Peptides 2009; 30:164-170.

106. Zhao Y, Lin MC, Mock A, Yang M, Wayne NL. Kisspeptins modulate the biology of multiple populations of gonadotropin-releasing hormone neurons during embryogenesis and adulthood in zebrafish (Danio rerio). PLoS One 9 2014; e104330

107. Zmora N, Stubblefield J, Zulperi Z, Biran J, Levavi-Sivan B, Muñoz-Cueto JA, et al. Differential and gonad stage-dependent roles of kisspeptin1 and kisspeptin2 in reproduction in the modern teleosts, morone species. Biol. Reprod 2012; 86:1-12.

108. Ogawa S, Sivalingam M, Anthonysamy R, Parhar IS. Distribution of Kiss 2 receptor in the brain and its localization in neuroendocrine cells in the zebrafish. Cell Tiss. Res 2020; 379:349-372.

109. Kanda S, Akazome Y, Mitani Y, Okubo K, Oka Y. Neuroanatomical evidence that kisspeptin directly regulates isotocin and vasotocin neurons. PLoS ONE 8 2013; e62776. https://doi. org/10.1371/journal.pone.0062776

110. Zmora N, Stubblefield JD, Wong TT, Levavi-Sivan B, Millar RP, Zohar Y. Kisspeptin 504 Antagonists Reveal Kisspeptin 1 and Kisspeptin 2 Differential Regulation of Reproduction in the 505 Teleost, Morone saxatilis. Biol Reprod 2015; 93:76.

111. Espigares F, Zanuy S, Gómez A. Kiss2 as a regulator of LH and FSH secretion via paracrine/autocrine signaling in the teleost fish European Sea Bass (Dicentrarchus labrax). Biol of Reprod 2015; 114:1-12.

112. Kitahashi, T. and Parhar, I. S. Comparative aspects of kisspeptin gene regulation. Gen. Comp. Endocrinol 2013; 181:197-202.

113. Beck BH, Fuller SA, Peatman E, McEntire, ME, Darwish A, Freeman DW. Chronic exogenous kisspeptin administration accelerates gonadal development in basses of the genus Morone. Comp Biochem Physiol 2012; 162:265-273.

114. Shi Y, Zhang Y, Li S, Liu Q, Lu D, Liu M, et al. Molecular identification of the Kiss2/Kiss1ra system and its potential function during 17 -methyltestosterone-induced sex reversal in the orange-spotted grouper, Epinephelus coioides. Biol Reprod 2010; 83:63-74.

115. Mechaly AS, Tovar-Bohórquez MO, Mechaly AE, Suku E, Pérez MR, Giorgetti $A$, et al. evidence of alternative splicing as a regulatory mechanism for Kissr2 in pejerrey fish. Front. Endocrinol 2018; 9-604.

116. Tsatsanis C, Dermitzaki E, Avgoustinaki P, Malliaraki N, Mytaras V, Margioris AN. The impact of adipose tissue-derived factors on the hypothalamic-pituitary-gonadal (HPG) axis. Hormones 2015; 14(4):549-562.
117. Castellano JM, Bentsen AH, Mikkelsen JD, Tena-Sempere M.Kisspeptins: bridging energy homeostasis and reproduction. Brain Res 2015; 1364:129-138.

118. De Bond JA, Smith JT. Kisspeptin and energy balance in reproduction. Reproduction 2015; 147:53-63.

119. Sawada K, Ukena K, Satake H, Iwakoshi E, Minakata H, Tsutsui K. Novel fish hypothalamic neuropeptide. Eur J Biochem 2002; 269:6000-6008.

120. Biswas S, Jadhao AG, Pinelli C, Palande NV, Tsutsui K. $\mathrm{GnIH}$ and GnRH expressions in the central nervous system and pituitary of Indian major carp, Labeo rohita during ontogeny: An immunocytochemical study. Gen Comp Endocrinol 2015; 220:8892.

121. Di Yorio MP, Sirkin P, Delgadin TH, Shimizu A, Tsutsui K, Somoza GM, et al. Gonadotrophin Inhibitory hormone in the cichlid fish Cichlasoma dimerus: structure, brain distribution and differential effects on the secretion of gonadotrophins and growth hormone. J Neuroendocrinol 2016; 28. https://doi.org/10.1111/ jne.12377.

122. Paullada-Salmerón JA, Cowan M, Aliaga-Guerrero M, Gómez A, Zanuy S, Mañanos, E, et al. LPXRFa peptide system in the European sea bass: A molecular and immunohistochemical approach. J Comp Neurol 2016; 524:176-198.

123. Ogawa S, Parhar IS. Structural and functional divergence of gonadotropininhibitory hormone from jawless fish to mammals. Front Endocrinol 2014; 5:177.

124. Wang Q, Qi X, Guo Y, Li S, Zhang Y, Liu X, et al. Molecular identification of $\mathrm{GnlH} / \mathrm{GnlHR}$ signal and its reproductive function in protogynous hermaphroditic orange-spotted grouper (Epinephelus coioides). Gen Comp Endocrinol 2015; 216:9-23.

125. Zhang Y, Li S, Liu Y, Lu D, Chen H, Huang X, et al. Structural diversity of the gnih/gnih receptor system in teleost: Its involvement in early development and the negative control of $\mathrm{LH}$ release. Peptides 2010; 31:1034-1043.

126. Ogawa S, Sivalingam M, Biran J, Golan M, Anthonysamy RS, Levavi-Sivan B, et al. Distribution of LPXRFa, a gonadotropin-inhibitory hormone ortholog peptide, and LPXRFa receptor in the brain and pituitary of the tilapia. J Comp Neurol 2016; 524:27532775.

127. Wang B, Yang G, Liu Q, Qin J, Xu Y, Li W, et al. Characterization of LPXRFa receptor in the half-smooth tongue sole (Cynoglossus semilaevis): Molecular cloning, expression profiles, and differential activation of signaling pathways by LPXRFa peptides. Comp. Biochem. Physiol. A Mol Integr Physiol 2018; 223:23-32.

128. Kriegsfeld LJ, Feng Mei D, Bentley GE, Ubuka T, Mason AO, Inoue $\mathrm{K}$, et al. Identification and characterization of a gonadotropin inhibitory system in the brains of mammals. PNAS 2006; 103(7):2410-2415

129. Ubuka T, Son YL, Tsutsui K. Molecular, cellular, morphological, physiological and behavioral aspects of gonadotropin-inhibitory hormone. Gen Comp Endocrinol 2016; 227:27-50.

130. Biran J, Golan M, Mizrahi N, Ogawa S, Parhar IS, Levavi-Sivan B. LPXRFa, the piscine ortholog of $\mathrm{GnIH}$, and LPXRF receptor positively regulate gonadotropinsecretion in tilapia (Oreochromis niloticus). Endocrinology 2014; 155 (11):4391- 4401.

131. Amano M, Moriyama S, ligo M, Kitamura S, Amiya, N, Yamamori K, et al. Novel fish hypothalamic neuropeptides stimulate the release of gonadotrophins and growth hormone from the pituitary of sockeye salmon. J Endocrinol 2006; 188: 417-423.

132. Moussavi M, Wlasichuk M, Chang JP, Habibi HR. Seasonal effect of $\mathrm{GnlH}$ on gonadotrope functions in the pituitary of goldfish. Mol Cell Endocrinol 2012; 350:53-60.

133. Shahjahan M, Ikegami T, Osugi T, Ukena K, Doi, H, Hattori A, et al. Synchronised expressions of LPXRFamide peptide and its receptor genes: seasonal, diurnal and circadian changes during spawning period in grass puffer. J. Neuroendocrinol 2011; 23, 3951.

134. Yan H, ljiri S, Wu Q, Kobayashi T, Li ST, Adachi S, Nagahama Y. Expression Patterns of Gonadotropin Hormones and Their Receptors During Early Sexual Differentiation in Nile Tilapia Oreochromis niloticus. Biology of Reproduction 2012; 116:1-11. 
135. Shupnik MA. Gonadotropin gene modulation by steroids and gonadotropin-releasing hormone. Biol. Reprod 1996; 54(2):279-286.

136. Burow S, Fontainea R, Von Krogha K, Mayerb I, Nourizadeh-Lillabadia R, Hollander-Cohenc $L$, et al. Medaka follicle-stimulating hormone (Fsh) and luteinizing hormone (Lh): Developmental profiles of pituitary protein and gene expression levels. General and Comparative Endocrinology 2018: 272:93-108.

137. Simoni M, Gromoll J, Nieschlag E. The follicle-stimulating hormone receptor: biochemistry, molecular biology, physiology, and pathophysiology. Endocr Rev 1997; 18:739-773.

138. Kumar RS, Trant JM. Piscine glycoprotein hormone gonadotropin and thyrotropin receptors: a review of recent developments. Comp Biochem Physiol 2001; 129:347-355.

139. Falcone T, Hurd WW. Clinical Reproductive Medicine and Surgery: A Practical Guide, DOI 10.1007/978-1-4614-6837-0_2 (C) Springer Science Business Media New York 2013.

140. Santos M, Rand-Weaver, Tyler CR. Follicle stimulating hormone and its alpha and beta subunits in rainbow trout (Oncorhynchus mykiss): Purification, characterization, development of radioimmunoassays, and their seasonal plasma and pituitary concentrations in females. Biol Reprod 2001; 65:288-294.

141. Vischer, Tevez, Ackermans, Van Dijk, Schulz y Bogerd J. Cloning and spatiotemporal expression of follicle-stimulating hormone $\otimes$ subunit complementary DNA in the African catfi sh (Clarius gariepinus). Biol. Reprod 2003: 68:1324-1332.

142. Schulz RW, Vischer HF, Cavaco JE, Santos EM, Tyler CR, Goos $\mathrm{HJ}$, et al. Gonadotropins, their receptors, and the regulation of testicular functions in fish. Comp Biochem Physiol B Biochem Mol Biol 2001; 129:407-417.

143. Kobayashi Y, Alam MA, Horiguchi R, Shimizu A, Nakamura M. Expresión Sexualmente dimórfico de subunidades de gonadotropina en la pituitaria de pro-mero panal togynous (Epinephelus merra): evidencia de que el folículo-estimulante hormone (FSH) induce el cambio de sexo gonadal. Biol Reprod 2010; 82:10301036.

144. Chang JP, Wong AOL. Growth hormone regulation in fish: a multifactorial model with hypothalamic, peripheral and local autocrine/paracrine signals. In: Fish Neuroendocrinology. Fish Physiology 28. Farrell AP, Brauner CJ (Eds). Academic Press, UK. 2009;151-195.

145. Dong $\mathrm{H}$, Zeng L, Duan D, Zhang H, Wang Y, Li W, et al. Growth hormone and two forms of insulin-like growth factors in the giant grouper (Epinephelus lanceolatus): molecular cloning and characterization of tissue distribution. Fish Physiol. Biochem 2010; 36:201-212.

146. Blanco AM. Hypothalamic and pituitary-derived growth and reproductive hormones and the control of energy balance in fish. General and Comparative Endocrinology 2020; doi: https://doi. org/ 10.1016/j.ygcen.2019.113322.

147. Canosa LF, Chang JP, Peter RE. Neuroendocrine control of growth hormone in fish. Gen Comp Endocrinology 2011; 151:1-26.

148. Bertucci JI, Blanco AM, Sundarrajan L, Rajeswari JJ, Velasco C, Unniappan S. Nutrient Regulation of Endocrine Factors Influencing Feeding and Growth in Fish. Frontiers in Endocrinology 2019; 10, Article 83

149. Pérez-Sánchez J, Calduch-Giner JA, Mingarro M, de CeLis SVR, Gomez-Requeni P, Saera-Vila A, et al. Overview of fish growth hormone family. New insights in genomic organization and heterogeneity of growth hormone receptors. Fish Physiol Biochem 2002: 27:243-58.

150. Reinecke M, Björnsson BT, Dickhoff WW, McCormick SD, Navarro I, Power DM, et al. Growth hormone and insulin-like growth factors in fish: where we are and where to go. Gen Comp Endocrinol 2005: 142:20-4

151. Brooks AJ, Waters MJ. The growth hormone receptor: mechanism of activation and clinical implications. Nat Rev Endocrinol 2010; 6:515-525.

152. Fukada H, Ozaki Y, Pierce AL, Adachi S, Yamauchi K, Hara A, et al. Salmon growth hormone receptor: molecular cloning ligand specificity, and response to fasting. Gen Comp Endocrinol 2004: 139:61-71.
153. Pierce AL, Fox BK, Davis LK, Visitacion N, Kitahashi T, Hirano $T$ et al. Prolactin receptor, growth hormone receptor, and putative somatolactin receptor in Mozambique tilapia: Tissue specific expression and differential regulation by salinity and fasting. Gen Comp. Endocrinol 2007; 154:31-40.

154. Reinecke M. Insulin-like growth factors and fish reproduction. Biol. Reprod 2010; 82: 656-661.

155. Daughaday WH. Growth hormone axis overview-somatomedin hypothesis. Pediatr Nephrol 2010; 14:537-540.

156. Reinecke $M$, Collet $C$. The phylogeny of the insulin-like growth factors. Int Rev Cytol 1998; 183:1-94.

157. Norbeck LA, Kittilson JD, Sheridan MA. Resolving the growth-promoting and metabolic effects of growth hormone: Differential regulation of GH-IGF-I system components. Gen Comp Endocrinol 2007; 151:332-341.

158. Zhou R, Yu SMY, Ge W. Expression and functional characterization of intrafollicular GH-IGF system in the zebrafish ovary. Gen Comp Endocrinol 2016; 232:32-42.

159. Pérez L, Ortiz-Delgado B, Manchado JM. Molecular characterization and transcriptional regulation by $\mathrm{GH}$ and $\mathrm{GnRH}$ of insulin-like growth factors I and II in White seabream (Diplodus sargus). Gene 2016; 578:251-262.

160. Breves JP, McCormick SD, Karlstrom RO. Prolactin and teleost ionocytes: New insights into cellular and molecular targets of prolactin in vertebrate epithelia. Gen. Comp Endocrinol 2014; 203:21-28

161. Dobolyi A, Oláh S, Keller D, Kumari R, Fazekas E, Csikós V Cservenák M. Secretion and function of pituitary prolactin in evolutionary perspective. Frontiers in Neuroscience 2020; 14, 621.

162. Imaoka T, Matsuda M, and Mori T. Extrapituitary expression of the prolactin gene in the goldfish, African clawed frog and mouse. Zool. Sci 2000; 17:791-796.

163. Boutet I, Lorin-Nebel C, De Lorgeril J, Guinand B. Molecular characterisation of prolactin and analysis of extrapituitary expression in the European sea bass Dicentrarchus labrax under various salinity conditions. Comp. Biochem. Physiol. D Genomics Proteomics 2007; 2:74-83.

164. Summers K, Zhu Y. Positive selection on a prolactin paralog following gene duplication in cichlids: adaptive evolution in the context of parental. Copeia 2008; 4: 872-876.

165. Sandra O, Le Rouzic P, Cauty C, Edery M, Prunet P. Expression of the prolactin receptor (tiPRL-R) gene in tilapia Oreochromis niloticus: Tissue distribution and cellular localization in osmoregulatory organs. J Mol Endocrinol 2000; 24:215-224.

166. Kawauchi H, Sower SA, Moriyama S. The Neuroendocrine Regulation of Prolactin and Somatolactin secretion in fish. Fish Physiology 2009; 28:197-234.

167. Edery M, Young G, Bern HA, Steiny S. Prolactin receptors in tilapia (Sarotherodon mossambicus) tissues: binding studies using I-125 labeled ovine prolactin. Gen Comp Endocrinol 1984; 56:19-23.

168. Ozaki Y, Ishida K, Saito K, Ura K, Adachi S, Yamauchi K. Immunohistochemical changes in production of pituitary hormones during artificial maturation of female Japanese eel Anguilla japonica. Fish Sci 2007; 73:574-584

169. Onuma TA, Ban M, Makino K, Katsumata H, Hu WW, Ando $\mathrm{H}$, et al. Changes in gene expression for GH/PRL/SL family hormones in the pituitaries of homing chum salmon during ocean migration through upstream migration. Gen Comp Endocrinol 2010; 166:537-548.

170. Power DM. Developmental ontogeny of prolactin and its receptor in fish. Gen. Comp. Endocrinol 2005; 142:25-33.

171. Whittington CM, Wilson AB. The role of prolactin in fish reproduction. Gen Comp Endocrinol 2013; 191:123-136.

172. Harvey S, Martínez-Moreno G, Luna M, Arámburo C. Autocrine/paracrine roles of extrapituitary growth hormone and prolactin in health and disease: An overview. Gen Comp Endocrinology 2014; 154:31-40.

173. Cyr DG, Eales JGG. Interrelation ships between thyroidal and reproductive endocrine systems in fish. Rev Fish Biol Fish 1996; 6:165-200. 
174. Cyr DG, Eales JGG. In vitro effects of TH on gonadotropin-induced estradiol-17 $\otimes$ secretion by ovarian follicles of rainbow trout, Salmo gairdneri. Gen Comp Endocrinol 1988; 69:80-87.

175. Blanton, ML, Specker JL. The Hypothalamic-Pituitary-Thyroid (HPT) axis in fish and its role in fish development and reproduction. Crit Rev Toxicol 2007; 37:97-115

176. Nelson ER, Allan ERO, Pang FY, Habibi HR. Thyroid hormone and reproduction: Regulation of estrogen receptors in goldfish gonads. Mol. Reprod. Dev 2010; 77:784-794.

177. Tovo-Neto A, Da Silva Rodríguez M, Habibi HR, Nóbrega RH. Thyroid hormone actions on male reproductive system of teleost fish., General and Comparative Endocrinology 2018; doi: https:// doi.org/10.1016/j.ygcen.2018.04.023

178. Yu L, Han Z, Liu C. A review on the effects of PBDEs on thyroid and reproduction systems in fish. Gen Comp Endocrinol 2015; http://dx.doi.org/10.1016/j.ygcen.2014.12.010

179. Mylonas, Sullivan, Hinshaw. Thyroid hormones in brown trout (Salmo trutta) reproduction and early development. Fish Physiol. Biochem 1994: 13:485-493.

180. Basset JHD, Harvey CB, Williams GR. Mechanisms of thyroid hormone receptor-specific nuclear and extra nuclear actions Mol Cell Endocrinol 2003; 213:1-11.

181. Brown L, Sullivan CV, Bern HA, Dickhoff WW. Occurrence of thyroid hormones in early developmental stages of teleost fish. Am. Fish Soc Symp 1987; 2:144-150.

182. Parhar IS, Soga T, Sakuma Y. Thyroid hormone and estrogen regulate brain region-specific messenger ribonucleic acids encoding three gonadotropin-releasing hormone genes in sexually immature male fish, Oreochromis niloticus. Endocrinology 2000; 141:1618-1626

183. Allan ER, Habibi, HR. Direct effects of triiodothyronine on production of anterior pituitary hormones and gonadal steroids in goldfish. Mol Reprod Dev 2012; 79:592-602.

184. Nelson ER, Habibi HR. Functional significance of nuclear estrogen receptor subtypes in the liver of goldfish. Endocrinology 2010; 151:1668-1676.

185. Nelson ER, Habibi HR. Thyroid hormone regulates vitellogenin by inducing estrogen receptor alpha in the goldfish liver. Mol Cell Endocrinol 2016; 436:259-267.

186. Morais RD, Nóbrega RH, Gómez-González NE, Schmidt R, Bogerd, J, França, LR, et al. Thyroid hormone stimulates the proliferation of sertoli cells and single type A spermatogonia in adult zebrafish (Danio rerio) testis. Endocrinology 2013; 154:4365-4376.

187. Eales JG, Plate EM, Adams BA, Allison WT, Martens G, Hawryshyn $\mathrm{CW}$. The effects of thyroxine or a $\mathrm{GnRH}$ analogue on thyroid hormone deiodination in the olfactory epithelium and retina of rainbow trout, Oncorhynchus mykiss, and sockeye salmon, Oncorhynchus nerka. Gen Comp Endocrinol 2006; 127:59-65.

188. Habibi, HR, Nelson E.R, Allan ERO. New insights into thyroid hormone function and modulation of reproduction in goldfish. Gen Comp Endocrinol 2012; 175:19-26.

189. Tokarz J, Möller G, de Angelis MH and Adamski J. Steroids in teleost fishes: a functional point of view. Steroids 2015 103:123-144.

190. Guyton JE. Elsevier AC. Tratado de Fisiología Médica (ed. Décimotercera edición, 2016).

191. Filby AL and Tyler CR. Molecular characterization of estrogen receptors $1,2 \mathrm{a}$, and $2 \mathrm{~b}$ and their tissue and ontogenic expression profiles in fathead minnow (Pimephales promelas). Biology of reproduction 2005; 73(4):648-662.

192. Borg B. Androgens in teleost fishes. Comp Biochem Physiol 1994; 109C (3):219-245.

193. Matty AJ. Gonadal Hormones. Fish endocrinology 1985; pp138-173. Croom Helm Ltd., London.

194. Lubzens E, Young G, Bobe J, Cerda, J. Oogenesis in teleosts: how fish eggs are formed. Gen Comp Endocrinol 2010; 165:367389.

195. Segner H, Van Kemenade BL, Chadzinska M. The immunomodulatory role of the hypothalamus-pituitary-gonad axis: Proximate mechanism for reproduction-immune tradeoffs? Developmental \& Comparative Immunology 2017; 66:43-60.
196. Soranganba N, Singh IJ. Role of Some Steroidogenic Hormones in Fish Reproduction., Chemical Science Review and Letters 2019, 8(29):64-69.

197. Canazas NR. Evolución Gonadal de Las Hembras de Trucha Arco iris (Oncorhynchus Mykiss) de la Piscigranja PumahuancaUrubamba, Tesis de Grado UNSAC, 119; 2015

198. Nagahama Y, Yamashita M. Regulation of oocyte maturation in fish. Development, growth \& differentiation 2008; 50(s1).

199. Devlin R.H, Nagahama Y. Sex determination and sex differentiation in fish: an overview of genetic, physiological, and environmental influences. Review article. Aquaculture 2002; 208:191-364.

200. Nagahama Y, Yoshikuni M, Yamashita M, Tanaka M. Regulation of oocyte maturation in fish. In: Sherwood, N.M., Hew, C.L. (Eds.), Fish Physiology. Academic Press, San Diego, CA, pp. 393439. Neurol 1994; 524:176-198.

201. Babin PJ, Carnevali O, Lubzens E, Schneider WJ. Molecular aspects of oocyte vitellogenesis in fish. Springer 2007:39-76.

202. Hiramatsu N, Matsubara T, Fujita T, Sullivan CV, Hara A Multiple piscine vitellogenins: biomarkers of fish exposure to estrogenic endocrine disruptors in aquatic environments. Mar Biol 2006; 149:35-47.

203. Stocco C, Telleria G, Gibori. The molecular control of corpus luteum formation, rolfunction, and regression. Endocr Rev 2007; 28:117-149.

204. Milla S, Wang N, Mandiki SN, Kestemont P. Corticosteroids: Friends or foes of teleost fish reproduction? Comparative Biochemistry and Physiology Part A: Molecular \& Integrative Physiology 2009; 153(3):242-251.

205. Kusakabe M, Nakamura I, Young G. 11beta-hydroxysteroid dehydrogenase complementary deoxyribonucleic acid in rainbow trout: cloning, sites of expression, and seasonal changes in gonads. Endocrinology 2003; 144:2534-2545.

206. Noaksson E, Linderoth M, Gustavsson B, Zebühr Y, Balk L. Reproductive status in female perch (Perca fluviatilis) outside a sewage treatment plant processing leachate from a refuse dump. Sci. Total Environ 2005; 340: 97-112.

207. Westring CG, Ando H, Kitahashi T, Bhandari RK, Ueda H, Urano A, et al. Seasonal changes in CRF-I and urotensin I transcript levels in masu salmon: correlation with cortisol secretion during spawning. Gen Comp Endocrinol 2008; 155:126-140.

208. Leibowitz, Wortley. Hypothalamic control of energy balance: different peptides, different functions. Peptides 2004: 25:473-504.

Received: 7 May 2021

Accepted: 4 August 2021 